\title{
Transaksi Pihak Terkait atas Biaya Audit: Peran Efektivitas Komite Audit
}

\author{
Dian Kristiyani ${ }^{1}$ \\ Fakultas Ekonomi dan Bisnis \\ Universitas Airlangga, Indonesia
}

\begin{abstract}
Surel : diankristiyan67@gmail.com
\section{ABSTRAK}

Tujuan dari penelitian ini adalah untuk menganalisis pengaruh transaksi pihak berelasi dan efektivitas komite audit terhadap biaya audit. Penelitian ini menggunakan sampel perusahaan non-finansial di Bursa Efek Indonesia (BEI) pada 2016-2018. Teknik pengambilan sampel menggunakan purposive sampling. Jumlah total perusahaan yang digunakan sebagai sampel penelitian adalah 118 perusahaan. Menggunakan alat SPSS 20 dan menguji hipotesis menggunakan regresi linier. Uji $F$ menunjukkan model yang stabil dan signifikan. R square adalah 58,7 persen. Hasilnya menunjukkan transaksi pihak berelasi berpengaruh signifikan positif dan efektivitas komite audit berpengaruh negatif signifikan terhadap biaya audit.
\end{abstract}

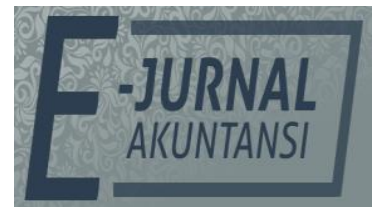

e-ISSN 2302-8556

Vol. 30 No. 10

Denpasar, Oktober 2020

Hal. 2619-2628

DOI:

10.24843/EJA.2020.v30.i10.p14

PENGUTIPAN:

Kristiyani, D. (2020).

Pengaruh Penerapan E-

Transaksi Pihak Terkait atas

Biaya Audit: Peran

Efektivitas Komite Audit. E-

Jurnal Akuntansi, 30(10), $2619-2628$

RIWAYAT ARTIKEL:

Artikel Masuk: 24 Juni 2020

Artikel Diterima: 23 Oktober 2020 118 companies. Using tools SPSS 20 and testing hypothesis using linear regression. The $F$ test indicates a stable and significant model. $R$ square is 58,7 percent. The results show that related party transactions have a significant positive effect and the effectiveness of the audit committee has a significant negative effect on audit fees.

Keywords: $\quad$ Related Party Transaction; Effectiveness Of Audit Committee; Audit Fee.

Artikel dapat diakses : https://ojs.unud.ac.id/index.php/Akuntansi/index 


\section{PENDAHULUAN}

Perusahaan di Indonesia PT Adaro Energy Tbk diduga melakukan transaksi pihak berelasi dengan anak perusahaan yakni Adaro di Singapura sehingga perusahaan ini terlibat kasus fraud. LSM Global Witness melaporkan dugaan penggelapan pajak oleh PT Adaro Energy Tbk dengan melarikan pendapatan dan labanya ke luar negeri. Coldrate anak perusahaan dari PT Adaro energy di singapura membeli batu bara dari perusahaan afiliasi di Indonesia dengan harga yang rendah dan dijual kembali dengan harga yang jauh lebih tinggi dari harga belinya. Transaksi pihak berelasi bisa menjadi penyebab kurangnya laporan normal dari pengalihan pendapatan serta dasar biaya dari satu pihak kepihak lainnya.

Related Party Transaction merupakan alternatif yang dapat dilakukan dalam aktivitas perusahaan untuk menjalankan bisnisnya. Transaksi dengan pihak berelasi meliputi aktivitas seperti penjualan dan pembelian aset, penjaminan pinjaman, dan pertukaran aset dengan kualitas yang berbeda. Ada dua pandangan yang bersaing tentang RPT. Di sisi positif, RPT dapat meningkatkan nilai karena dapat digunakan oleh kelompok bisnis untuk berbagi sumber daya, mengurangi biaya transaksi, dan sebagai hasilnya meningkatkan pengembalian aset. Dari sisi negatifnya, RPT sering dianggap tidak baik; misalnya, RPT dapat digunakan secara oportunistik oleh pemegang saham pengendali yang menangani sendiri untuk mengambil manfaat pribadi dengan mengorbankan pemegang saham minoritas (Al-Dhamari et al, 2017).

Dalam literatur akuntansi, banyak penelitian tentang RPT fokus pada RPT terhadap kualitas laba, masih sangat sedikit penelitian yang meneliti pada respon auditor terhadap RPT (Habib et al, 2015), semakin banyak perusahaan terlibat dalam RPT, semakin banyak tantangan yang dihadapi auditor eksternal dan internal. Karena RPT sangat mungkin melanggar asumsi panjang lengan, auditor biasanya melihatnya sebagai "red flag". Levine et al, (1997) berpendapat bahwa karena transparansi yang rendah dan RPT yang rumit dapat mengakhibatkan auditor merasa sulit untuk memahami dan mengaudit transaksi tersebut. Selain itu, American Institute of Certified Public Accountants (AICPA) menganggap RPT sebagai sulit untuk diaudit dan indikator potensial risiko audit (AICPA 2001).

Teori Agensi menunjukan bahwa transaksi pihak berelasi dapat menimbulkan isu keagenan, masalah agensi muncul ketika manajer dengan tindakan oportunitistiknya memaksimalkan pendapatan mereka sendiri dan merugikan pemegang saham (Jensen \& Meckling, 1976). Manajer dapat mementingkan diri sendiri melalui transaksi pihak berelasi dengan mengambilalih sumber daya perusahaan dan mengalikan kekayaan dari perusahaan ke keuntungan pribadi (Gordon \& Henry, 2005). Transaksi berelasi meningkatkan salah saji material yang mengakhibatkan upaya yang lebih dilakukan oleh auditor, hal tersebut menyebabkan biaya audit dapat lebih tinggi dari perusahaan yang lebih banyak melakukan transaksi dengan pihak berelasi (Habib, Jiang, \& Zhou, 2015) dan (Al-Dhamari et al, 2017).

$\mathrm{H}_{1}$ : transaksi pihak berelasi berpengaruh positif terhadap biaya audit. 


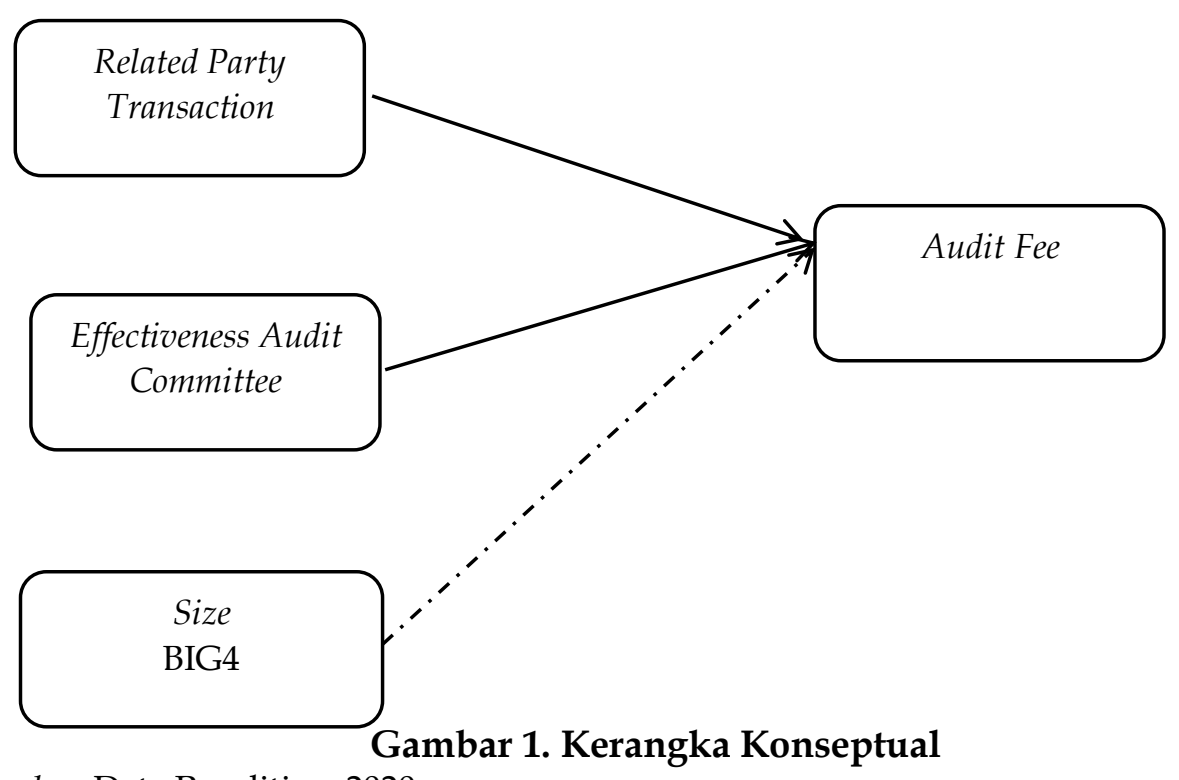

Sumber: Data Penelitian, 2020

Tata kelola dalam perusahaan harus dijalankan dengan baik untuk mengurangi masalah agensi yang lebih besar sesuai dengan standar yang diterapkan. Tata kelola perusahaan berkaitan dengan fungsi pengawasan yang dilakukan oleh dewan komisaris dengan membentuk komite di bawah mereka, salah satunya adalah Komite Audit (Ariningrum \& Diyanty, 2017). Masalah agensi yang besar pada perusahaan yang melakukan transaksi dengan pihak berelasi dapat berkurang ketika tata kelola dalam perusahaannya dijalankan dengan baik.

Argumen pertama dalam pada sisi permintaan yang dijelaskan oleh Hey et al, (2006) biaya audit yang dibayar oleh perusahaan ditentukan oleh perusahaan sebagai pengguna. Efektivitas fungsi pengawasan yang dilakukan oleh Dewan Komisaris dan dibantu oleh Komite Audit. Perusahaan meminta kualitas layanan audit yang lebih tinggi dan meminta prosedur audit lebih menyeluruh. Hal ini dapat berimplikasi pada tingginya jumlah biaya audit yang dibebankan auditor. Sisi penawaran yang dilihat melalui perspektif auditor. Komite audit yang efektif dapat meningkatkan kualitas tata kelola perusahaan. Auditor percaya bahwa resiko inheren dapat lebih rendah apabila komite audit dalam perusahaan efektif menjalankan tugasnya, pada akhirnya kan mengurangi biaya audit yang dibebankan kepada perusahaan (Wahab et al, 2011).

Komite audit yang independen dan memiliki keahlian keuangan dapat meningkatkan kualitas laporan keuangan, pengungkapannya lebih transparan dan lebih efektif dalam melakukan proses audit internal (Owens-Jackson et al, 2009), (Qinghua et al, 2007) dan (Salehi \& Shirazi, 2016). Ittonen et al, (2010) menemukan bahwa komposisi komite audit yang berkualitas diyakini dapat meningkatkan tingkat pengawasan dan pengendalian internal, sehingga mengurangi risiko yang dimiliki oleh perusahaan. Risiko yang lebih kecil ini pada akhirnya dapat mengurangi biaya audit karena berkurangnya prosedur pengujian substantif yang perlu dilakukan oleh auditor (Knechel \& Willekens, 2006). oleh karena itu komite audit yang efektif dapat menurunkan biaya audit (Wahab et al, 2011) dan (Sitompul, 2019). 
$\mathrm{H}_{2}$ : Efektivitas Komite Audit berpengaruh negatif terhadap biaya audit.

\section{METODE PENELITIAN}

Populasi penelitian ini merupakan seluruh perusahaan manufaktur yang terdaftar di Bursa Efek Indonesia (BEI) tahun 2016-2018. Penelitian ini menggunakan jenis data sekunder yang diambil dari informasi yang tersaji pada Annual Report. Sebanyak 118 perusahaan terpilih menjadi sampel penelitian berdasarkan teknik purposive sampling dengan kriteria pada

\section{Tabel 1. Kriteria Sampel}

\begin{tabular}{|c|c|c|c|c|}
\hline \multirow[b]{2}{*}{ No } & \multicolumn{4}{|c|}{2016} \\
\hline & Kriteria Sampel & & 2017 & 2018 \\
\hline 1 & $\begin{array}{l}\text { Perusahaan manufaktur yang } \\
\text { terdaftar di BEI }\end{array}$ & 138 & 143 & 145 \\
\hline 2 & $\begin{array}{l}\text { Laporan keuangan tidak dapat } \\
\text { diakses }\end{array}$ & (19) & (15) & (11) \\
\hline 3 & $\begin{array}{l}\text { Perusahaan yang tidak } \\
\text { mengungkapkan biaya audit }\end{array}$ & (64) & (65) & (67) \\
\hline 4 & $\begin{array}{l}\text { Perusahaan yang tidak melakukan } \\
\text { transaksi dengan pihak berelasi }\end{array}$ & (22) & (23) & (22) \\
\hline & Total & 33 & 40 & 45 \\
\hline & Total Observasi & 118 & & \\
\hline
\end{tabular}

Sumber: Data Penelitian, 2020

Variabel dependen penelitian adalah biaya audit yang didefiniskan sebagai jumlah biaya yang harus dikeluarkan oleh setiap perusahaan untuk membiayai jasa auditor eksternal yang telah melakukan audit atas laporan keuangan perusahaan yang bersangkutan. Biaya audit diukur dengan logaritma natural biaya audit yang terdapat dalam laporan keuangan.

Variabel independen yang pertama adalah transaksi pihak berelasi adalah suatu pengalihan sumber daya, jasa atau kewajiban antara entitas pelapor dengan pihak-pihak yang berelasi, terlepas apakah terdapat harga yang dibebankan atau tidak. Transaksi ini dapat berupa transaksi bisnis yang kompleks antara perusahaan dan manajer, direktur, pemilik utama atau 
afiliasinya sendiri. Hubungan pihak berelasi dapat dilihat dari substansi hubungan tidak hanya dalam bentuk hukum hubungan tersebut (Wong, Kim, \& Lo, 2015) dan (Cheng \& Leung, 2014). RPT_Sales dapat dirumuskan sebagai berikut.

$$
\text { RPT Sales }=\frac{\text { Related party sales }}{\text { Unrelated party sales }}
$$

Variabel independen yang kedua adalah efektivitas komite audit, efektivitas komite audit merupakan komite audit yang memenuhi syarat untuk melindungi kepentingan dari pemegang saham untuk memastikan bahwa pelaporan keuangan andal, pengendalian internal, dan risiko manajemen, melalui upaya melaksanakan pengawasan dengan tekun (Ika dan Ghazali, 2012). Efektivitas komite audit yang diukur dengan indeks komposit (EFFAC5) dikonfirmasi ketika kelima karakteristik hadir. Lima karakteristik gabungan adalah sebagai berikut: independensi komite audit (IAC), keahlian komite audit (ACEXP), ketekunan komite audit (ACD), ukuran komite audit (SAC) dan ketua komite audit dengan keahlian akuntansi (ACCHX). Sistem skor digunakan dimana nilai dikotomis dari " 1 " atau " 0 " untuk setiap karakteristik komite audit yang efektif (Ali et al, 2018).

Variabel Kontrol penelitian adalah kantor akuntan public dan ukuran perusahaan. Kantor akuntan publik diukur dengan variabel dummy. Kode 1 diberikan pada perusahaan yang menggunakan jasa akuntan publik big 4 dan kode 0 diberikan pada perusahaan yang menggunakan jasa akuntan publik non big 4 (Simunic, 1980).

Adapun teknik analisis yang digunakan meliputi analisis statistika deskriptif, uji asumsi klasik uji hipotesis (Ghozali, 2011). Analisis statistika deskriptif berisi informasi mengenai karakteristik data penelitian berupa nilai minimum, nilai maksimum, nilai rata-rata dan standar deviasi. Pengujian hipotesis dilakukan menggunakan analisis regresi linear berganda. Model persamaan regresi moderasi dalam penelitian ini sebagai berikut.

AudFeeit $=\alpha_{0}+\beta_{1}$ RPT_SALES $_{i t}+\beta_{3}$ EFFACit $+\beta_{4}$ BIG4it $+\beta_{5}$ SIZEit $+\varepsilon i t$

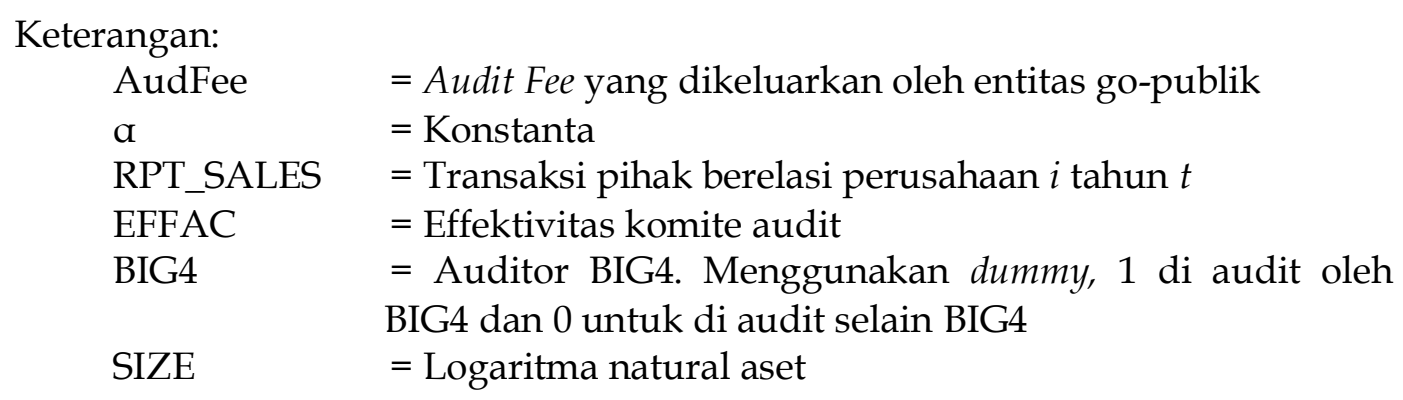

\section{HASIL DAN PEMBAHASAN}

Berdasarkan tabel statistik deskriptif, dapat diketahui bahwa variabel dependen dalam penelitian ini yaitu biaya audit memiliki nilai rata-rata sebesar 20.8392 dalam rupiah berarti $\mathrm{Rp} 825$ juta, ini berarti bahwa rata-rata perusahaan di Indonesia pada 2017 sampai 2018 membayar jumlah biaya audit sebesar Rp 825 juta kepada auditor. Rentang ini cukup tinggi pada variabel ini, dilihat dari 
perbedaan antara nilai maksimum dan minimum, menggambarkan bahwa sampel perusahaan dalam penelitian ini mewakili jumlah nominal biaya audit dari kecil ke besar.

Variabel independen pertama dalam penelitian ini adalah transaksi pihak berelasi yang diukur dengan penjulan dibagi dengan penjualan pada pihak berelasi digunakan dalam penelitian (Wong, Kim, \& Lo, 2015), (Cheng \& Leung, 2014), (Chen, Chen, \& Chen, 2014). Nilai rata-rata yang diperoleh adalah 0.1057. Hasil menunjukan bahwa rata-rata sampel dalam perusahaan memiliki 10,5 persen transaksi dengan perusahaan yang memiliki hubungan relasi dengan perusahaan tersebut.

Variable independen kedua dalam penelitian adalah efektivitas komite audit yang diukur dengan skor dikomposit yang digunakan dalam penelitian (Ali et al, 2018) rata-rata skor didapatkan 0,7983 yang berarti komite audit di Indonesia rata-rata memiliki skor 4 pada perusahaan manufajtur.

Variabel control yang pertama yakni ukuran perusahaan yang diukur menggunakan logaritma natural dari asset. Hasil penelitian menunjukan ratarata ukuran perusahaan bernilai 28,812, yang berarti rata-rata jumlah aset perusahaan manufaktur yang mengungkapkan biaya audit senilai 3,2 trilliun.

Variable control kedua yakni kantor akuntan publik diukur menggunakan dummy, skor 1 apabila perusahaan menggunakan jasa kantor akuntan publik BIG4 dan skor 0 apabila menggunkaan jasa akuntan public selain BIG4. Hasil dari penlitian didapatkan 58 perusahaan menggunakan kantor akuntan public BIG4 dengan presentase 49,2 persen. Perusahaan yang tidak menggunakan akuntan bulig BIG4 sejumlah 60 perusahaan dengan presentase 50,8 persen.

Tabel 2. Statistik Deskriptif

\begin{tabular}{|c|c|c|c|c|c|}
\hline & $\mathrm{N}$ & Minimum & Maximum & Mean & Std. Deviation \\
\hline AudFee & 118 & 18.50 & 23.32 & 20.8392 & 1.07307 \\
\hline PRT & 118 & .01 & 3.81 & 1.1047 & .81376 \\
\hline AFFAC & 118 & 0.4 & 1.00 & 0.7983 & 0.17046 \\
\hline SIZE & 118 & 19.81 & 31.68 & 28.8129 & 1.80492 \\
\hline $\begin{array}{l}\text { Valid } \\
\text { (listwise) }\end{array}$ & 118 & & & & \\
\hline \multicolumn{6}{|c|}{ Variabel Dummy } \\
\hline Variabel & & \%Score1 & \%Score0 & \multicolumn{2}{|c|}{ total $\%$} \\
\hline BIG4 & & (58) $49.2 \%$ & (60) $50.8 \%$ & \multicolumn{2}{|c|}{ 100\% } \\
\hline
\end{tabular}


Model penelitian ini sudah layak dilakukan uji regresi linear berganda karena sudah lolos dari uji asumsi klasik.

Nilai adjusted $R 2$ sebesar 0,587 yang artinya variabel independen mampu menjelaskan variabel dependen sebesar 58,7 persen sementara 41,3 persen sisanya dipengaruhi oleh faktor lain diluar model penelitian. Hasil dari hipotesis pertama pengaruh transaksi pihak berelasi terhadap biaya audit menunjukan nilai signifikansi 0,000 dan koefisien positif yang menunjukan bahwa transaksi pihak berelasi berpengaruh positif terhadap biaya audit. Hasil dari hipotesis kedua pengaruh efektivitas komite audit terhadap biaya audit menunjukan nilai signifikansi 0,004 dan koefisien negatif yang menunjukan bahwa efektivitas komite audit berpengaruh negatif terhadap biaya audit.

Tabel 3. Uji Statistik

\begin{tabular}{llll}
\hline \multirow{2}{*}{ Variabel } & \multicolumn{3}{c}{ Regresi Linier Berganda } \\
\cline { 2 - 4 } (Constantat) & $\mathrm{B}$ & $\mathrm{T}$ & Sig \\
RPT & 17,781 & 15,584 & 0,000 \\
EFFAC & 0,475 & 5,623 & 0,000 \\
KAP & $-1,201$ & $-2,938$ & 0,004 \\
SIZE & 0,892 & 6,317 & 0,000 \\
Adjustes R & 0,098 & 2,720 & 0,008 \\
F-value & 0,587 & & \\
Sig & 42,623 & & \\
\hline
\end{tabular}

Sumber: Data Penelitian, 2020

Hasil penelitian yang dilakukan pada model penelitian ini menunjukan bahwa hasilnya konsisten dengan hipotesis pertama yang menyatakan bahwa transaksi pihak berelasi berpengaruh positif signifikan terhadap biaya audit. Pada tingkat signifikansi sebesar $1 \%(0.000<0.01)$, sehingga $\mathrm{H}_{1}$ diterima. Penjelasan hasil dalam penelitian ini yakni perusahaan yang melakukan transaksi dengan pihak berelasi dapat meningkatkan resiko yang dimiliki perusahaan sehingga auditor eksternal melakukan pemeriksaan lebih dengan effort yang lebih dari perusahaan yang tidak beresiko tinggi sehingga dapat meningkatkan biaya audit yang dibayarkan oleh perusahaan (Al-Gamrh et al, 2017) dan (Erasandi, 2020).

Sudut pandang Agency theory yang menyakatakan bahwa transaksi pihak berelasi dapat menyebabkan kerugian perusahaan yang diakhibatkan oleh tindakan oportunistik. Hal tersebut mengakhibatkan resiko lebih tinggi dimiliki oleh perusahaan yang melakukan penjulan dengan pihak berelasi. Perusahaan yang memiliki resiko yang tinggi, sesuai dengan teori dan hasil empiris bahwa perusahaan yang melakukan transaksi pihak berelasi membayar biaya audit lebih tinggi dari perusahaan yang tidak melakukan transaksi dengan pihak berelasi. 
Hasil penelitian yang dilakukan untuk hipotesis pertama menunjukan bahwa hipotesis kedua dalam penelitian ini diterima. Hipotesis kedua menyatakan bahwa efektivitas komite audit berpengaruh negatif terhadap biaya audit. Tingkat signifikansi sebesar $1 \%(0.004<0.01)$, sehingga $\mathrm{H}_{1}$ diterima. Penjelasan hasil dalam penelitian ini biaya audit dilihat dari perspektif auditor sebagai penyedia jasa audit yang harus dibayarkan (Hey et al, 2006). Komite audit yang efektif meningkatkan tata kelola. Auditor percaya bahwa resiko yang dimiliki perusahaan bisa diminimalisir dengan komite audit yang efektif dalam menjalankan fungsinya, pada akhirnya akan menurunkan biaya audit yang harus dibayarkan pada perusahaan (Wahab et al, 2011).

Hasil penelitian mendukung teori Good Corporate Goveenance. Komite audit yang efektif dapat meningkatkan kualitas tata kelola perusahaan. Auditor percaya bahwa resiko inheren dapat lebih rendah apabila komite audit dalam perusahaan efektif menjalankan tugasnya, pada akhirnya kan mengurangi biaya audit yang dibebankan kepada perusahaan (Wahab et al, 2011) dan (Nurjanah \& Sudaryati, 2019). Hasil penelitian ini mendukung teori penentuan biaya audit yang menyatakan bahwa komite audit dapat menurunkan biaya audit dikarenakan biaya audit dapat diminimalisir dengan adnya komite audit yang efektif.

\section{SIMPULAN}

Penelitian ini bertujuan untuk menganalisis pengaruh transaksi pihak berelasi dan efektivitas komite audit terhadap biaya audit. Berdasarkan pengujian hipotesis pertama ditemukan bahwa adanya transaksi pihak berelasi dalam perusahaan berpengaruh positif signifikan terhadap biaya audit. Perusahaan yang memiliki transaksi pihak berelasi dianggap memiliki risiko lebih tinggi daripada perusahaan lain yang tidak melakukan transaksi dengan relasi dan akibatnya auditor akan meningkatkan upaya audit yang diperlukan dan implikasinya terhadap biaya audit yang tinggi yang dibebankan (Habib, Jiang, \& Zhou, 2015) dan (Al-Gamrh, Ismail, \& Ismail, 2017). Hipotesis kedua ditemukan efektivitas komite audit berpengaruh negatif signifikan terhadap biaya audit. Hasil ini mendukung argument dari sisi penawaran Komite audit yang efektif dapat meningkatkan kualitas tata kelola perusahaan. Auditor percaya bahwa resiko inheren dapat lebih rendah apabila komite audit dalam perusahaan efektif menjalankan tugasnya, pada akhirnya kan mengurangi biaya audit yang dibebankan kepada perusahaan.

Penelitian ini memiliki keterbatasan, yang pertama masih sedikitnya perusahaan yang mengungkapkan biaya audit dalam laporan tahunannya. Saran untuk penelitian selanjutnya bisa menjadikan variabel efektivitas komite audit menjadi variable moderasi antara hubungan transaksi pihak berelasi dan biaya audit.

\section{REFERENSI}

Al-Gamrh, R. A. A. B., Ismail, K. N. I. K., \& Ismail, S. S. H. (2017). Related party transactions and audit fees : the role of the internal audit function. Journal of Management \& Governance. https:/ / doi.org/10.1007/s10997-017-9376-6 
Ali, M. J., Singh, R. K. S., \& Al-Akra, M. (2018). The impact of audit committee effectiveness on audit fees and non-audit service fees: Evidence from Australia. Accounting Research Journal, 31(2), 174-191.

Ariningrum, I., \& Diyanty, V. (2017). The Impact of Political Connections and the Effectiveness of Board of Commissioner and Audit Committees on Audit Fees The Impact of Political Connections and the Effectiveness of Board of. 11(4), 53-70. https:// doi.org/10.14453/aabfj.v11i4.5

Atanasov, V., Black, B., \& Ciccotello, C. S. (2014). UNBUNDLING AND MEASURING TUNNELING *. 1697-1738.

Chen, Y., Chen, C. H., \& Chen, W. (2014). The Impact of Related Party Transactions on The Operational Performance of Listed Companies in China. Journal of Economic Policy Reform, 12(December), 285-297. https:// doi.org/https:/ / doi.org/10.1080/17487870903314575

Cheng, M., \& Leung, N. W. (2014). Ownership Structure, Ongoing Related Party Transaction and Corporate Performance: Evidenced from Chinese Listed Firms. Corporate Ownership \& Control, 11(2), 446-464. https:// doi.org/10.22495/cocv11i2c5p2

Ghozali, I. (2013). Analisis Multivariate dengan Program IBM SPSS 21: Semarang: Universitas Diponegoro.

Gordon, E. A., \& Henry, E. (2005). Related Party Transactions and Earnings Management.

Habib, A., Jiang, H., \& Zhou, D. (2015). Related-Party Transactions and Audit Fees: Evidence from China. Journal of International Accounting Research, 14(1), 59-83.

Jensen, M. C., \& Meckling, W. H. (1976). Theory of the firm: Managerial behavior, agency costs and ownership structure. Journal of Financial Economics, 3(4), 305-360. https:/ / doi.org/10.1016/0304-405X(76)90026-X

Jian, M., \& Wong, T. J. (2004). Earnings Management and Tunneling through Related Party Transactions : Evidence from Chinese Corporate Groups .

Knechel, W. R., \& Willekens, M. (2006). The role of risk management and governance in determining audit demand. Journal of Business Finance $\mathcal{E}$ Accounting, 33(9-10), 1344-1367.

Kohlbeck, M., \& Mayhew, B. W. (2010). Valuation of firms that disclose related party transactions. Journal of Accounting and Public Policy, 29(2), 115-137.

Owens-Jackson, L. A., Robinson, D., \& Waller Shelton, S. (2009). The association between audit committee characteristics, the contracting process and fraudulent financial reporting. American Journal of Business, 24(1), 57-66.

Salehi, M., \& Shirazi, M. (2016). Audit committee impact on the quality of financial reporting and disclosure: Evidence from the Tehran Stock Exchange. Management Research Review, 39(12), 1639-1662.

Simunic, D. A. (1980). The Pricing of Audit Service: Theory and Evidence. Jurnal of Accounting Research, 18(1), 161-190.

Tuanakotta, T. M. (2015). Audit Kontemporer. Jakarta: salemba empat.

Qinghua, W., Pingxin, W., \& Junming, Y. (2007). Audit committee, board characteristics and quality of fi nancial reporting: An empirical research on Chinese securities market. Frontiers of Business Research in China, 1(3), 385400. 
Simunic, D. A. (1980). The pricing of audit services: Theory and evidence. Journal of accounting research, 161-190.

Sitompul,Freddy.(2019). Pengaruh mekanisme good corporate governance dan biaya audit terhadap perusahaan karakteristik eksternal. IkraithEkonomika,2(1).

Wahab, E. A. A., Zain, M. M., \& James, J. (2011). Political connections, corporate governance and audit fees in Malaysia. Managerial Auditing Journal, 26(5), 393-418.

Wong, R. M. K., Kim, J., \& Lo, A. W. Y. (2015). Are Related-Party Sales ValueAdding or Value-Destroying? Evidence from China. Journal of International Finance Manangement $\mathcal{E}$ Accounting, 26(1), 1-38. https:// doi.org/https://doi.org/10.1111/jifm.12023 